\title{
WAJAH DEMOKRASI JAKARTA DALAM POTRET INDEKS DEMOKRASI INDONESIA (IDI)
}

\author{
Oleh: Rahmatulloh*
}

\begin{abstract}
ABSTRAK
Kajian ini bertujuan untuk mendeskripsikan perkembangan demokrasi lokal di Propinsi Daerah Khusus Ibukota Jakarta berdasarkan capaian Indeks Demokrasi Indonesia (IDI) dalam kurun 5 tahun terakhir (2013-2017). Metode yang digunakan adalah, studi pustaka (library research), wawancara mendalam, Focus Group Discussion, dan analisa konten dokumen pemberitaan. Hasil kajian menunjukkan capaian indeks demokrasi Propinsi DKI Jakarta menempati posisi tertinggi, dibandingkan dengan propinsi-propinsi lain. Pada tahun 2014 skor indeks demokrasi Propinsi DKI mencapai 84,70, dari skala 100. Pada tahun 2015 skor indeks mencapai 85,32, tahun 2016 merosot menjadi 70,85. Sementara tahun 2017 mencapai peringkat tertinggi, yakni 84,73. Dengan demikian, Jakarta merupakan sebuah "barometer" nasional bagi capaian demokrasi. Dinamika dan kinerja demokrasi di Propinsi DKI Jakarta sangat dipengaruhi kedudukannya sebagai Ibukota negara, kota metropolitan, pusat kehidupan politik, ekonomi, sosial budaya.
\end{abstract}

Kata Kunci: Indeks Demokrasi, Politik Lokal, Perkembangan Demokrasi.

\begin{abstract}
This study aims to describe the development of local democracy in the Special Capital Region of Jakarta based on the achievement of the Indonesian Democracy Index (IDI) in the last 5 years (2013-2017). The methods used are library research, in-depth interviews, Focus Group Discussion, and analysis of news document content. The results of the study show that the achievements of the democracy index of DKI Jakarta Province occupy the highest position, compared to other provinces. In 2014 DKI Province's democracy index score reached 84.70, from a scale of 100. In 2015 the index score reached 85.32, 2016 dropped to 70.85. While 2017 reaches the highest ranking, which is 84.73. Thus, Jakarta is a national "barometer" for the achievement of democracy. The dynamics and performance of democracy in DKI Jakarta Province is strongly influenced by its position as the capital city, metropolitan city, the center of political, economic, socio-cultural life.
\end{abstract}

Keywords: Index of Democracy, Local Politics, Development of Democracy.

* Dosen Universitas Indraprasta PGRI Jakarta. Email:rahmat.algharamy@ gmail.com 


\section{PENDAHULUAN}

\section{A. Latar Belakang}

Dalam penelitian yang diungkap Unesco tahun 1950 bahwa untuk pertama kali dalam sejarah, demokrasi dinyatakan sebagai nama yang paling baik dan wajar untuk semua sistem organisasi politik dan sosial yang diperjuangkan oleh para pendukungnya yang berpengaruh. Demokrasi seolah menegaskan diri sebagai sistem yang terbaik dari semua sistem politik yang ada. Meskipun terdapat kritik atas kekurangan yang dimiliki, namun demokrasi dianggap paling sedikit keburukannya dari keburukan yang dimiliki sistem di luarnya.

Demokrasi kini sudah menjadi trend global di berbagai negara di dunia. Kehadirannya sebagai "anak kandung" dalam bangunan politik Barat kini telah diadopsi sebagai milik masyarakat dunia. Demokrasi tidak hanya mewabah pada negara dalam arti teritoral yang bersifat tunggal dan tersentralisasi, tetapi juga "merembes" hingga menjadi trend politik lokal di tiap-tiap wilayah sebagai bangunan sistem politik dari keberadaannya sebagai negara demokrasi. Artinya bagi negara, demokrasi kini telah menyentuh aspek lokalitas politik masyarakat sesuai kondisi, tradisi dan budaya yang melatarinya.

Konon, sekarang ini lebih dari 70 negara di berbagai belahan dunia sudah mulai melaksanakan reformasi politik dan demokrasi yang berujung pada desentralisasi dan pemberdayaan pemerintahan lokal (Maxim, 2002:v). Dalam demokrasi lokal, setidaknya terdapatnya peran atau kiprah instansiinstansi pemerintah lokal seperti gubernur di tingkat Provinsi dan walikota atau bupati di tingkat Kota/Kabupaten, DPRD, termasuk dewan kota, dan pelayanan administratif; serta adanya aktivitas masyarakat yang terorganisasi (civil society). Dari konteks tersebut, dimana para aparat pemerintah dan elit politik lokal dan gerakan masyarakat sipil memiliki peran saling mengisi dalam pengambilan keputusan dan terdapatnya hubungan yang saling mendukung untuk mengidentifikasi pelbagai permasalahan yang dihadapi dalam rangka mencari solusi di wilayah yang menjadi otonominya.

Perkembangan terkini, penguatan demokrasi lokal menjadi ukuran bagi keberhasilan demokrasi secara nasional dalam suatu negara. Bahwa untuk melihat perkembangan demokrasi di Indonesia, diperlukan pengukuran bagi 
keadaan demokrasi di tiap-tiap provinsi. Melalui pengukuran model IDI (Indeks Demokrasi Indonesia) yang telah dibakukan oleh para pakar/ahli dan difasilitasi oleh Kemenkopolhukam, BAPPENAS, Kemendagri, BPS dan dukungan UNDP sejak 2007, maka dapat diketahui tingkat demokratisnya masing-masing provinsi sehingga diakumulasi menurut agregasi capaian rata-rata keseluruhan atau secara nasional untuk melihat capaian demokrasi Indonesia. Uniknya melalui pengukuran ini juga dapat dilihat sejauhmana peringkat demokrasi tiaptiap provinsi untuk kemudian dapat dijadikan penyusunan bagi prioritas pembangunan politik oleh pemerintah maupun pemerintah daerah.

DKI Jakarta sebagai pusat pemerintahan dan daerah otonomi khusus sering disebut sebagai kota "barometer nasional" dalam pembangunan politik demokrasi juga tidak luput dalam obyek pengukuran IDI. Bahwa diketahui DKI Jakarta berhasil menempati angka tertinggi dalam capaian indeks demokrasi dibanding provinsi yang lain di Indonesia dan bahkan sebaliknya pernah terpuruk ke peringkat 14 dari 34 Provinsi pada 2016, dan bangkit kembali ke peringkat pertama pada
2017, dan dalam variabel tertentu juga terdapat capaian yang rendah dan kerap muncul setiap tahunnya. Hal ini tentu diperlukan suatu kajian mengenai aspek pengukuran IDI bagi peningkatan capaian indeks dari variabel tersebut dan sekaligus pemanfaatan hasilnya bagi pembangunan di DKI Jakarta, serta kelemahannya dalam pengukuran dan manfaat IDI terkait.

\section{B. Metode}

Metode pengumpulan dan pengolahan data yang digunakan dalam kajian ini menggunakan studi pustaka (library research) sebagai bahan literatur yang dapat menyajikan data dan disertai dokumen pendukung yang menjadi referensi penting dalam kajian ini, meliputi dokumen publikasi dari BPS DKI Jakarta, Focus Group Discussion, dan dokumen pemberitaan.

\section{KERANGKA KONSEPTUAL}

\section{A. Demokrasi Klasik Ke Demokrasi}

\section{Modern}

Kebanyakan negara di dunia meyakini demokrasi sebagai basis legitimasi bagi kedaulatan kekuasaan negara karena mencerminkan dukungan rakyatnya. Mengingat demokrasi menggunakan "tolok ukur tak terbantah dari keabsahan politik" sebagai 
pencerminan atas kehendak aspirasi penghuninya. Keyakinan bahwa kehendak rakyat adalah dasar utama bagi otoritas negara sebagai basis bagi tegak kokohnya sistem politik.

Jika di masa lalu, yakni Yunani kuno, demokrasi diyakini merupakan bagian dari bentuk-bentuk pemerintahan alternatif dalam penyusunan negara. Sebagaimana menurut Plato, kala itu membentuk pemerintahan dibedakan menjadi: monarki, tirani, aristokrasi, oligarki, demokrasi, dan mobokrasi/okhlokrasi. Bahkan kemudian, Polybios membuatnya menjadi semacam siklus politik kekuasaan sebagai proses pergantian atas semua bentuk pemerintahan sebagaimana menurut Plato dimaksud.

Pada fase berikutnya, di era modern demokrasi tidak lagi menjadi suatu bentuk pemerintahan melainkan sebagai sistem politik yang cakupannya lebih luas. Mengingat keberadaannya mengejawantahkan segala bentuk prosedur yang mesti ditempuh dalam membangun konstruksi bagi institusi negara, sehingga berbagai aspek yang melatari bagian-bagiannya seperti kebebasan hak sipil dan politik serta supremasi hukum diperlukan pelembagaan atau institusionalisasi demokrasi.

Sebagaimana Henry B. Mayo, menyatakan demokrasi sebagai sistem politik merupakan suatu sistem yang menunjukkan bahwa kebijakan umum ditentukan atas dasar mayoritas oleh wakil-wakil rakyat yang diawasi secara efektif oleh rakyat dalam pemilihan berkala yang didasarkan atas prinsip kesamaan politik dan diselenggarakan dalam suasana terjaminnya kebebasan politik.

Namun belakangan ini, demokrasi tidaklah cukup sebagai sistem politik bagi bangunan negara demokrasi modern. Sebab kehadirannya membutuhkan "support" dari berbagai pandangan hidup dan perilaku politik yang demokratis dari individu selaku pemilik kedaulatan. Di sinilah demokrasi mesti diartikan sebagai sikap hidup para individu pendukungnya yang menopang tegaknya politik demokrasi sebagai sistem. Demokrasi memerlukan praktik demokratis untuk tumbuh kembangnya negara demokrasi. Praktik atas perilaku demokrasi terkait dengan nilai-nilai demokrasi yang dipegang teguh atau telah tumbuh sebagai kesadaran politik sehingga akan membentuk budaya atau kultur demokrasi. 
Nilai-nilai yang membangun kultur demokrasi penting untuk terwujudnya sistem demokrasi. Henry B Mayo dalam Mirriam Budiardjo (1990) menyebutkan adanya delapan nilai demokrasi, yaitu; (1) Menyelesaikan pertikaian-pertikaian secara damai dan suka rela; (2) Menjamin terjadinya perubahan secara damai dalam suatu masyarakat yang selalu berubah; (3) Pergantian penguasa dengan teratur; (4) Penggunaan paksaan sesedikit mungkin; (5) Pengakuan dan penghormatan terhadap nilai keanekaragaman; (6) Menegakan keadilan; (7) Memajukan ilmu pengetahuan; dan (8) Pengakuan dan penghormatan terhadap kebebasan. Menurut Mirriam Budiardjo (1997) menyatakan bahwa untuk melaksanakan nilai-nilai demokrasi perlu diselenggarakan lembaga-lembaga, antara lain sebagai berikut:

a. Pemerintahan yang bertanggung jawab.

b. Suatu dewan perwakilan rakyat yang mewakili golongan dan kepentingan dalam masyarakat yang dipilih melalui pemilihan umum yang bebas dan rahasia agar lembaga ini melakukan pengawasan terhadap pemerintah. c. Suatu organisasi politik yang mencakup lebih dari suatu partai. Dan melalui partai menyelanggarakan fungsi politiknya sebagai pelembagaan politik masyarakat.

d. Pers dan media masa yang bebas untuk menyatakan pendapat.

e. Sistem peradilan yang bebas untuk menjamin hak asasi manusia dan mempertahankan keadilan.

Sedangkan Mouffe (1996) dalam bahasan Budiarto Danujaya (2012;xv) mengenai perpektif demokrasi menurutnya bahwa yang beredar luas saat ini adalah perpaduan antara gagasan kuno Yunani mengenai "kuasa dari rakyat" dan gagasan modern sejak era renaisance akhir dan pencerahan abad XVIII sampai paruh abad XX mengenai "hak-hak individual yang dijamin secara hukum". Sehingga demokrasi mengalami liberalisasi sebagaimana pendapat MacPherson “demokrasi diliberalisasikan". Dalam Budiarto Danujaya (2012;157 dan 207) bahwa liberalisme sebagai paradigma modernisme berbicara batas-batas kuasa negara karena legitimasi politik negara berlandaskan dari dan untuk pemenuhan hak-hak warga negara. Hak-hak asasi manusia sebagai limit yang menentukan asas negara hukum 
pada ketatanegaraan demokrasi konstitusional.

\section{B. Pengukuran Demokrasi}

Amien Rais (1986: xvii-xxv) dalam kata pengantar buku Demokrasi dan Proses Politik yang merupakan kumpulan hasil jurnal LP3ES menyatakan bahwa demokrasi sulit untuk didefinisikan secara baku, apalagi jika hanya digambarkan dengan bentukbentuk formal yang seringkali menyesatkan. Sehingga menurutnya lebih tepat disusun kriteria demokrasi untuk memahami hakikatnya sebagai ukuran untuk menentukan sudah seberapa jauhkah suatu negara mencoba menerapkan demokrasi dalam tata politik dan pemerintahannya. Sejumlah kriteria tersebut menurutnya adalah: (1) Partisipasi rakyat dalam pembuatan keputusan; (2) Persamaan di depan hukum; (3) Distribusi pendapatan secara adil; (4) Kesempatan pendidikan yang sama; (5) Empat macam kebebasan (kebebasan berpendapat, kebebasan pers, kebebasan berkumpul/berserikat, dan kebebasan beragama); (6) Ketersediaan dan keterbukaan informasi;

Mengindahkan Fatsoen (etika) politik;

(8) Kebebasan individu (privacy); (9) Semangat kerjasama sesuai kesepakatan nilai-nilai luhur (konsensus); (10) Hak untuk protes (koreksi). Menurutnya sejumlah kriteria itu diperlukan sebagai referensi, sebab berhasil atau tidaknya suatu praktek hanya dapat ditentukan bila praktek ini dihadapkan dengan teori. Baginya untuk menilai suatu realitas hanya dapat dilakukan bila kenyataan itu dikonfontasikan dengan dimensi yang ideal.

G. Bingham Powell (1982) dalam Pangi Syarwi Chaniago (2017:182-183) menjelaskan bahwa suatu negara yang menyelenggarakan demokrasi perlu dilihat dari sejumlah kriteria yang dipersyaratkannya antara lain:

1. the legitimacy of the government rest on claim to represent the desires of its citizen. That is, the claimof the government to obedience to its laws is based on the governments assertion to be doing what they want it to do.

2. the organized arrangement that regulated this bargain of legitimacy is competitive political election. Leader are can choose among alternative candidate. In practice at lest plotical parties that have a change of winning are needed ato make such choice meaningful. 
3. most adults can paticipate in the electoral process, both as voter and the candidate for importants political office.

4. citizen voter are secret and not coerced.

5. citizens and leaders enjoy basic freedom of speech, press, assembly, and organization. Both established parties and new ones work to gain members and voters.

Sebagaimana dijelaskan, bahwa demokrasi bukan lagi semata-mata persoalan pemenuhan hak dipilih dan memilih, yakni ketersediaan kesempatan untuk ikut dalam kompetisi dalam jabatan politik, mapun partisipasi warga dalam menggunakan hak memilih (prosedur demokrasi), namun juga demokrasi modern meniscayakan terjaminnya penyelenggaraan kebebasan sipil dan politik. Demokrasi secara substansi menempatkan pada kebebasan, kesetaraan, keadilan, dan pemenuhan hak-hak asasi dalam lembaga-lembaga demokrasi.

Mengingat kebebasan sipil merupakan salah satu inti dari konsepsi demokrasi, maka menurut Gastil (1993) dalam Maswadi Rouf, dkk (2012;17) konsepsi tersebut terdapat dalam dua dimensi yang berbeda aspek: yakni
Hak-hak Politik (Political Rights) dan Kebebasan Sipil (Civi Liberty).

Kini, tingkat demokrasi suatu negara telah diukur menurut penilaian yang telah dibakukan secara obyektif sesuai konsep-konsep demokrasi yang telah disederhanakan sesuai kerangka konseptual dalam bentuk variabel operasional yang dapat diukur secara ilmiah. Bahwa suatu negara dapat disebut paling demokratis, cukup demokratis hingga kurang demokratis, berdasarkan parameter demokrasi yang diukur menurut suatu pengukuran indikator pada variabel indeks secara kuantitatif.

Sebagaimana lembaga ternama Freedom House yang melakukan pengukuran tingkat demokrasi negaranegara di dunia setiap dua tahun melalui skoring atas variabel-variabel demokrasi seperti kebebasan sipil dan politik, dan The Economist yang mengeluarkan Democracy Index setiap tahun, maka di Indonesia kini terdapat pengukuran tersendiri bernama Indeks Demokrasi Indonesia atau disingkat IDI (Maswadi Rouf, dkk., 2012;15).

IDI dipraktikan di Indonesia melalui pengukuran atas variabelvariabel demokrasi yang khas Indonesia, sehingga tidak sepenuhnya mengikuti instrumen yang 
dikembangkan dari luar. Sebagaimana praktik demokrasi tidak semata melibatkan struktur atau lembaga demokrasi tetapi juga melibatkan masyarakat sipil secara luas melalui perilaku yang mendukung suatu sistem, sehingga IDI juga menempatkan partisipasi masyarakat yang juga merupakan bagian yang diukur karena turut berpengaruh bagi pengukuran demokrasi.

\section{Indeks Demokrasi Indonesia (IDI)}

IDI yang telah dimulai sejak 2007 diselenggarakan dengan mendapatkan sokongan dari program pembangunan PBB bernama UNDP melibatkan stake holders demokrasi meliputi pemerintah, pemerintah provinsi, masyarakat sipil, dan akademisi. Dengan demikian, IDI memberikan gambaran tentang wajah demokrasi lokal setiap provinsi yang ada di Indonesia. Tinggi, sedang, atau rendahnya tingkat demokrasi suatu provinsi dapat dilihat dari kinerja hasil pengukuran IDI yang dilakukan kelompok kerja (Pokja) terdiri para stake holder yang ada di tiap provinsi.

Indeks Demokrasi Indonesia (IDI) adalah ukuran tingkat perkembangan demokrasi Indonesia dengan menilai dinamika demokrasi yang terjadi di tingkat provinsi. IDI dirancang untuk memberikan gambaran dengan jelas mengenai naik turunnya kualitas demokrasi di daerah. Sebagaimana penjelasan bahwa "Demokrasi Lokal yang kuat dan efektif merupakan dasar utama dalam mewujudkan demokrasi di tingkat nasional yang sehat dan kuat" dalam Demokrasi di Tingkat Lokal, Buku Panduan International IDEA Mengenai Keterlibatan, Keterwakilan, Pengelolaan Konflik dan Kepemerintahan. Sarah Maxim, Penyunting (2002:1).

IDI mengukur kualitas demokrasi suatu provinsi yang di dalamnya menilai kondisi dan dinamika demokrasi yang telah terjadi selama satu tahun. IDI bukanlah untuk mengevaluasi kinerja pemerintah, meskipun hasilnya bisa dimanfaatkan untuk menjadi suplemen dalam menyusun pembangunan politik agar terjadi peningkatan kualitas demokrasi sehingga wajah demokrasi di daerahnya dapat mengalami perbaikan.

IDI tidak semata mengukur peran pemerintah dalam kebijakan pembangunan tetapi juga peran institusi publik lainnya, yakni peradilan dan kepolisian, hingga peran partai politik dan masyarakat yang turut berkontribusi bagi terciptanya tatanan demokrasi. Sebab IDI mengidentifikasi 
berbagai persoalan yang menghambat internalisasi demokrasi di tingkat lokal, baik pemerintah maupun masyarakatnya. Pengukuran dilakukan setiap tahunnya agar dapat dimanfaatkan hasilnya, yakni dijadikan pedoman dalam perencanaan dan kebijakan pembangunan serta memberikan dukungan bagi program pengembangan dan penguatan demokrasi.

Aspek yang diukur dalam IDI meliputi kebebasan sipil, hak-hak politik, dan lembaga demokrasi, mengingat dalam konseptualisasi IDI dijelaskan bahwa esensi demokrasi yang secara konseptual ada aspek kebebasan sipil, hak-hak politik yang kemudian didukung oleh struktur dan prosedur lembaga demokrasi perlu dilakukan penyederhanaan konsep secara obyektif dalam beberapa variabel dan indikator yang dapat diukur, sebagaimana berikut:

1. Kebebasan Sipil (civil liberty):

1) Kebebasan Berkumpul dan Berserikat (2 indikator)

2) Kebebasan Berpendapat (2 indikator)

3) Kebebasan Berkeyakinan (3 indikator)

4) Kebebasan dari Diskriminasi (3 indikator)

2. Hak-Hak Politik (political rights):
5) Hak Memilih dan Dipilih (5 indikator)

6) Partisipasi Politik dlm Pengambilan Keputusan dan Pengawasan Pemerintahan (2 indikator)

\section{Lembaga Demokrasi (institution of} democracy):

7) Pemilu yang Bebas dan Adil (2 indikator)

8) Peran DPRD (3 indikator)

9) Peran Partai Politik (2 indikator)

10) Peran Birokrasi Pemerintah Daerah (2 indikator)

11) Peradilan yang Independen $(2$ indikator)

Metode yang dipakai dalam IDI adalah metode trianggulasi dengan kombinasi antara kuantitatif dan kualitatif sehingga data yang diperoleh dari metode yang satu akan memvalidasi silang (cross validate) data yang diperoleh metode lainnya. Sehingga metodologi pengumpulan data digunakan sebagai berikut:

1. Review (koding) berita dari surat kabar.

2. Review (koding) dokumen.

3. Focus Group Discussion (FGD) dengan berbagai kalangan/stakeholders

4. Indept Interview/wawancara mendalam

Dari data indeks atas masingmasing indikator dari aspek dan 
variabel di atas dihitung menjadi komposit indeks dalam IDI melalui penentuan Bobot, penghitungan dengan Analitical Hierarchy Procedure (AHP) dan Skala Kinerja Demokrasi. Capaian tingkat demokrasi dalam IDI digunakan skala $0-100$. Skala ini merupakan skala normatif di mana 0 adalah tingkat terendah dan 100 adalah tingkat tertinggi, dan kemudian dibagi ke dalam tiga kategori tingkat demokrasi yakni:

a. Kategori "baik" (indeks > 80);

b. Kategori "sedang" (indeks $60-80$ ); dan

c. Kategori "buruk" (indeks < 60).

\section{PEMBAHASAN}

\section{A. Capaian Demokrasi di DKI Jakarta}

\section{Berdasarkan Hasil IDI}

Tahun 2017 merupakan tahun politik di DKI Jakarta yang banyak menyita perhatian masyarakat Indonesia, yakni diselenggarakannya pesta Pemilukada 2017 untuk menentukan Gubernur dan Wakil Gubernur masa bakti 2017-2022. Di tengah tingginya tensi politik, pada 2018 dirilis berita resmi statistik oleh BPS DKI Jakarta pada 3 September 2018, bahwa Capaian hasil IDI DKI Jakarta 2017 secara keseluruhan cukup menakjubkan, yakni mencapai angka sebesar 84,73 (skala 0 sampai 100). Bila dibandingkan dengan capaian IDI DKI Jakarta 2016 yang sebesar 70,85, jelas pada tahun 2017 ini angkanya mengalami kenaikan secara signifikan.

Dengan hasil pengukuran tersebut, maka IDI DKI Jakarta 2017 berada pada kategori baik, dibandingkan capaian IDI tahun 2016 yang berada pada kategori sedang, dan bahkan berada di urutan ke-14 atau tercecer dari hasil capaian Provinsi lainnya di Indonesia.

Hasil capaian IDI tahun 2017 tersebut menunjukkan IDI DKI Jakarta menempati posisi tertinggi atau peringkat pertama perkembangan demokrasinya dan mengulang pada prestasi demokrasi dua tahun sebelumnya, yakni IDI tahun 2015 dimana perolehannya DKI mencapai 85,32 dan IDI tahun 2014 sebesar 84,70 .

Dengan demikian, hasil capaian demokrasi menurut catatan IDI 2017, maka perolehan IDI Provinsi DKI Jakarta menjadi yang tertinggi capaiannya di Indonesia dan bersama tiga provinsi lainnya, yakni DI Jogyakarta, Kalimantan Utara, dan Bangka Belitung berada pada kategori baik karena memiliki indeks di atas angka 80. 
Jika dilihat dari tabel di bawah ini, pada 2017 DKI Jakarta memperoleh 84,73 disusul oleh DI Yogyakarta $(83,61)$, Kalimatan Utara $(81,06)$, dan Bangka Belitung $(80,11)$. Hal tersebut dapat dilihat sebagaimana tabel 1 berikut: ${ }^{1}$

${ }^{1}$ Data Statistik BPSDKI Jakarta sesuai berita resmi No. 69/08/th.XXI, 15 Agustus 2018 
JURNAL ILMIAH MIMBAR DEMOKRASI

VOLUME 18, NOMOR 2, APRIL 2019

Tabel 1. IDI seluruh Provinsi se-Indonesia berdasarkan 3 Aspek Tahun 2016-2017

\begin{tabular}{|c|c|c|c|c|c|c|c|c|c|}
\hline \multirow[b]{2}{*}{ Kode } & \multirow[b]{2}{*}{ Provinsi } & \multirow[b]{2}{*}{ IDI } & \multicolumn{3}{|c|}{ IDI 2016} & \multirow[b]{2}{*}{ IDI } & \multicolumn{2}{|c|}{ IDI 2017} & \multirow[b]{2}{*}{$\begin{array}{c}\text { Aspek } \\
\text { Lembaga } \\
\text { Demokrasi }\end{array}$} \\
\hline & & & $\begin{array}{c}\text { Aspek } \\
\text { Kebebasan } \\
\text { Sipil }\end{array}$ & $\begin{array}{l}\text { Aspek Hak- } \\
\text { Hak Politik }\end{array}$ & $\begin{array}{c}\text { Aspek } \\
\text { Lembaga } \\
\text { Demokrasi }\end{array}$ & & $\begin{array}{c}\text { Aspek } \\
\text { Kebebasan } \\
\text { Sipil }\end{array}$ & $\begin{array}{l}\text { Aspek Hak- } \\
\text { Hak Politik }\end{array}$ & \\
\hline (1) & (2) & (3) & (4) & (5) & (6) & (7) & (8) & (9) & (10) \\
\hline 11 & Aceh & 72,48 & 92,92 & 63,94 & 60,33 & 70,93 & 87,27 & 63,94 & 61,47 \\
\hline 12 & Sumatera Utara & 67,37 & 82,71 & 62,29 & 56,13 & 68,08 & 74,75 & 62,29 & 68,87 \\
\hline 13 & Sumatera Barat & 54,41 & 51,01 & 54,33 & 58,82 & 69,50 & 61,66 & 61,08 & 92,72 \\
\hline 14 & Riau & 71,89 & 71,78 & 77,98 & 62,34 & 73,41 & 82,03 & 66,57 & 73,41 \\
\hline 15 & Jambi & 68,89 & 84,39 & 65,63 & 54,58 & 74,12 & 86,81 & 62,08 & 77,27 \\
\hline 16 & Sumatera Selatan & 80,95 & 91,17 & 81,94 & 66,53 & 74,04 & 90,83 & 63,90 & 69,03 \\
\hline 17 & Bengkulu & 74,23 & 85,14 & 63,84 & 77,01 & 72,73 & 88,51 & 59,42 & 74,03 \\
\hline 18 & Lampung & 61,00 & 60,49 & 59,32 & 64,31 & 72,01 & 74,12 & 67,20 & 77,00 \\
\hline 19 & Kepulauan Bangka Belitung & 83,00 & 87,65 & 81,09 & 80,20 & 80,11 & 83,07 & 82,30 & 72,89 \\
\hline 21 & Kepulauan Riau & 72,84 & 85,43 & 71,28 & 59,48 & 76,33 & 90,84 & 71,45 & 65,82 \\
\hline 31 & DKI Jakarta & 70,85 & 81,11 & 67,54 & 63,19 & 84,73 & 87,73 & 80,86 & 87,12 \\
\hline 32 & Jawa Barat & 66,82 & 73,37 & 72,34 & 49,79 & 68,78 & 73,61 & 71,02 & 59,16 \\
\hline 33 & Jawa Tengah & 66,71 & 66,06 & 67,24 & 66,69 & 70,85 & 69,07 & 67,24 & 78,82 \\
\hline 34 & DI Yogyakarta & 85,58 & 90,00 & 81,59 & 86,37 & 83,61 & 93,25 & 82,31 & 73,55 \\
\hline 35 & Jawa Timur & 72,24 & 73,73 & 76,49 & 63,63 & 70,92 & 78,98 & 60,98 & 76,57 \\
\hline 36 & Banten & 71,36 & 83,47 & 68,30 & 60,99 & 73,72 & 85,16 & 63,87 & 74,98 \\
\hline 51 & Bali & 78,95 & 96,94 & 69,60 & 71,18 & 78,80 & 95,51 & 66,80 & 76,85 \\
\hline 52 & Nusa Tenggara Barat & 65,41 & 65,06 & 62,08 & 71,13 & 76,04 & 79,40 & 62,08 & 93,98 \\
\hline 53 & Nusa Tenggara Timur & 82,49 & 96,25 & 81,68 & 66,46 & 75,51 & 79,69 & 69,75 & 79,39 \\
\hline 61 & Kalimantan Barat & 75,28 & 83,29 & 75,70 & 64,54 & 79,13 & 97,15 & 76,36 & 60,85 \\
\hline 62 & Kalimantan Tengah & 74,77 & 84,98 & 70,66 & 68,43 & 76,12 & 95,58 & 56,69 & 82,50 \\
\hline 63 & Kalimantan Selatan & 73,43 & 61,04 & 83,58 & 72,89 & 76,25 & 60,16 & 81,09 & 88,79 \\
\hline 64 & Kalimantan Timur & 73,64 & 78,25 & 78,35 & 60,36 & 72,86 & 83,33 & 67,18 & 68,72 \\
\hline 65 & Kalimantan Utara & 76,98 & 100,00 & 66,64 & 64,48 & 81,06 & 98,57 & 68,54 & 78,93 \\
\hline 71 & Sulawesi Utara & 76,34 & 96,31 & 70,42 & 60,62 & 75,76 & 90,87 & 72,12 & 62,54 \\
\hline 72 & Sulawesi Tengah & 72,20 & 80,39 & 67,89 & 68,76 & 69,79 & 90,04 & 55,88 & 66,44 \\
\hline 73 & Sulawesi Selatan & 68,53 & 75,54 & 61,51 & 70,86 & 70,79 & 77,48 & 64,58 & 72,23 \\
\hline 74 & Sulawesi Tenggara & 71,13 & 88,07 & 55,51 & 74,66 & 68,51 & 77,66 & 60,49 & 69,74 \\
\hline 75 & Gorontalo & 77,48 & 82,35 & 75,54 & 74,42 & 73,92 & 85,30 & 68,18 & 68,73 \\
\hline 76 & Sulawesi Barat & 72,37 & 82,89 & 69,02 & 64,47 & 67,74 & 73,56 & 60,84 & 71,39 \\
\hline 81 & Maluku & 78,20 & 87,17 & 76,18 & 70,13 & 77,45 & 81,78 & 74,85 & 76,15 \\
\hline 82 & Maluku Utara & 73,27 & 92,27 & 61,79 & 67,59 & 70,73 & 90,19 & 65,84 & 54,02 \\
\hline 91 & Papua Barat & 60,35 & 93,67 & 38,05 & 53,85 & 62,76 & 92,42 & 39,05 & 63,14 \\
\hline 94 & Papua & 61,02 & 92,15 & 41,13 & 53,45 & 61,34 & 89,09 & 42,16 & 56,91 \\
\hline & Indonesia & 70,09 & 76,45 & 70,11 & 62,05 & 72,11 & 78,75 & 66,63 & 72,49 \\
\hline
\end{tabular}


Total angka secara keseluruhan di atas menjadikan Jakarta merupakan sebuah "barometer" nasional bagi capaian demokrasi, meski ini menjadi catatan untuk terus diperbaiki. Mengingat masih terdapat beberapa kelemahan dari aspek dan indikator tertentu yang masih tertinggal dari angka atau indeks aspek dan indikator dari provinsi lain. Misal pada aspek Kebebasan Sipil yang peroleh DKI Jakarta $(87,73)$ masih di bawah Kalimantan Utara $(98,57)$, Kalimantan Barat (97,15), Kalimantan Tengah $(95,58)$, DI Yogyakarta $(93,25)$, bahkan Papua Barat $(92,42)$ dan lain sebagainya. Pada aspek Hak-Hak Politik, DKI Jakarta $(80,86)$, di bawah DI Jogyakarta (82,31), Kep. Bangka Belitung (82,30), dan Kalimantan Selatan (81,09). Sedangkan pada Aspek Lembaga Demokrasi diperoleh DKI Jakarta $(87,12)$, masih di bawah NTB $(93,98)$, dan Sumatera Barat $(92,72)$.

Sejak diberlakukan IDI bagi seluruh provinsi di Indonesia pada 2009 hingga kini, Jakarta selalu bertengger pada posisi teratas, meskipun awalnya berada pada ketegori sedang dan meningkat menjadi kategori baik pada 2014 dan 2015. Namun pada 2016 mengalami penurunan pada kategori sedang dan berada pada peringkat ke-14, tetapi akhirnya pada 2017 kembali naik teratas. Dengan demikian, sejak 2009 hingga 2017 di IDI DKI Jakarta mengalami naik-turun sebagaimana berikut:

a. Pada 2009 sebesar 73,91 (Kategori Sedang);

b. Pada 2010 sebesar 77,44 (Kategori Sedang);

c. Pada 2011 sebesar 77,81 (Kategori Sedang);

d. Pada 2012 sebesar 77,72 (Kategori Sedang);

e. Pada 2013 sebesar 71,18 (Kategori Sedang);

f. Pada 2014 sebesar 84,70 (Kategori Baik);

g. Pada 2015 sebesar 85,32 (Kategori Baik).

h. Pada 2016 sebesar 70,85 (Kategori Sedang).

i. Pada 2017 sebesar 84,73 (Kategori Baik).

Selanjutnya, untuk memudahkan perbandingan capaian IDI dari tahun ke tahun tersebut, maka secara sederhana dapat dilihat grafiknya pada tabel 2 berikut: 
Tabel 2 Perkembangan IDI Provinsi DKI Jakarta 2009-2007

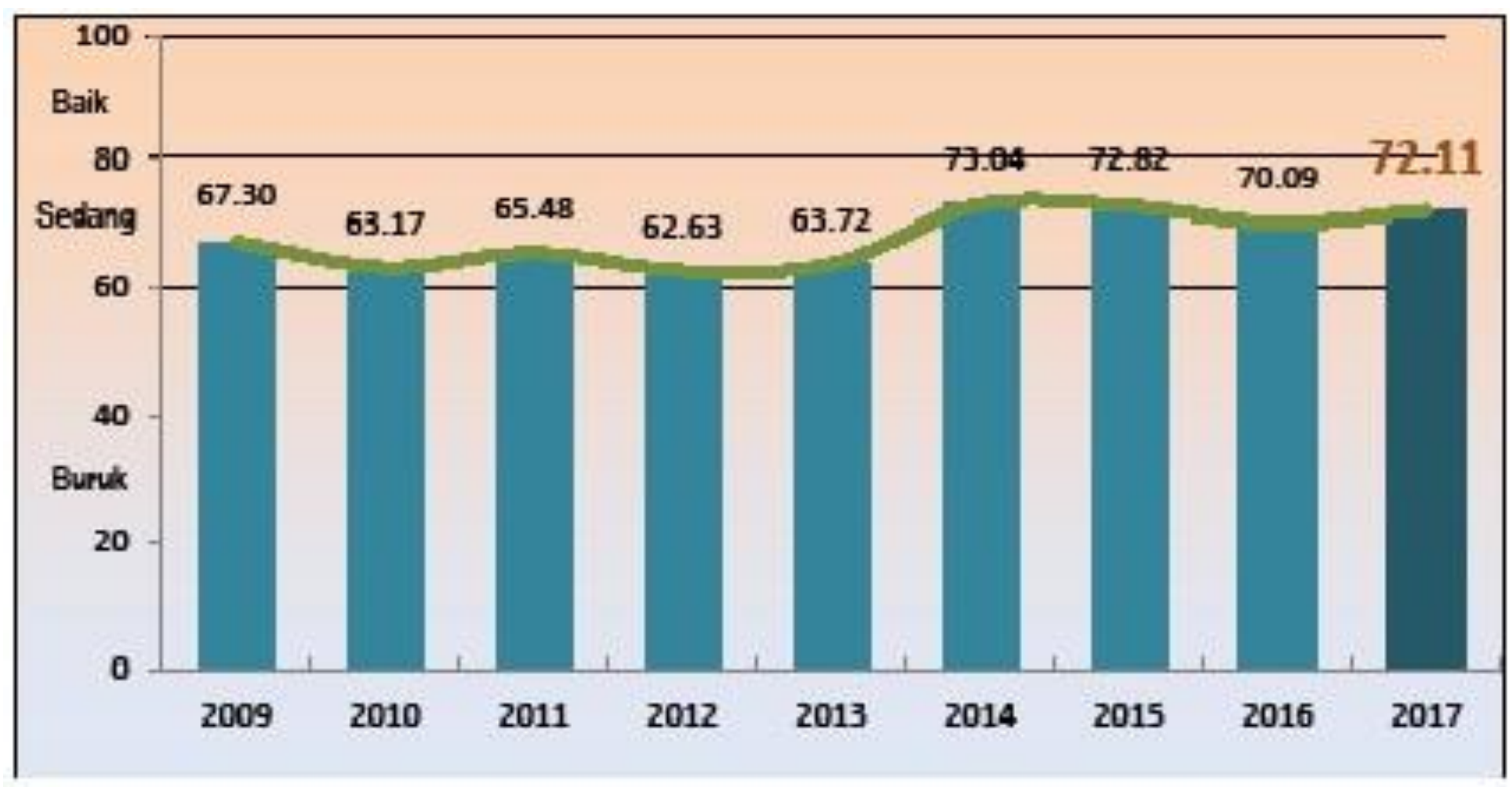


Dari nilai IDI DKI Jakarta tahun 2017 di atas, meskipun mengalami kenaikan dari kategori "sedang" menjadi kategori "baik" atau teratas, namun masih terdapat variabel aspek dan indikator yang mesti diperbaiki mengingat ada beberapa angka mengalami penurunan. Penurunan angka tersebut menunjukkan adanya kekurangan-kekurangan perlu mendapat perhatian dari semua kalangan pelaku demokrasi di Ibukota Jakarta, bahkan dari kekurangan tersebut sebenarnya pernah tergambar atau terjadi secara berulang karena belum mengalami perbaikan atau perubahan oleh pengambil kebijakan ataupun stakeholders demokrasi di Jakarta.

\section{B. Capaian Indeks Dalam Variabel} IDI DKI Jakarta Tahun Lima Tahun Terakhir

Bahwa peningkatan IDI DKI Jakarta dari tahun ke tahun selalu dipengaruhi perubahan tiga aspek demokrasi, yaitu: (1) Kebebasan Sipil (Civil Liberty); (2) Hak-Hak Politik (Political Rights), dan; (3) Lembagalembaga Demokrasi (Institution of Democracy). Dari 3 aspek tersebut, secara keseluruhan terdapat 11 variabel yang diukur melalui indikatornya masing-masing.

\section{Capaian IDI DKI Jakarta Tahun} 2013

Berdasarkan data lima tahun terakhir, setidaknya dapat tergambar capaian perkembangan tentang naikturunnya nilai IDI DKI Jakarta. Dalam Tabel 2 di atas, pada tahun 2013, capaian IDI DKI Jakarta mengalami penurunan $(71,18)$ atau lebih rendah dari tahun sebelumnya, bahkan sejak tahun 2009 yang mencapai $(73,91)$. Hal tersebut didapati dari ketiga aspek yang diukur tersebut salah satunya Aspek tentang Hak-Hak Politik (Political Rights) dalam kategori buruk, sedangkan Lembaga-lembaga Demokrasi (Institution of Democracy) turun dari kategori sedang menjadi kategori buruk. Berbeda dengan Aspek Kebebasan Sipil (Civil Liberty) yang tetap stabil dalam kategori baik.

Diantara 11 variabel yang mengalami penurunan terdapat 5 variabel, yang memperoleh skor terendah adalah Peran partai politik turun 77,14 poin dari 87,14 (2012) menjadi 10,00 (2013). Disusul 4 variabel lainnya, yakni Hak memilih dan dipilih turun 0,34 poin dari 52,98 menjadi 52,64, Partisipasi politik 
dalam pengambilan keputusan dan pengawasan turun 14,54 poin dari 72,06 menjadi 57,52, Kebebasan Berpendapat turun 22,23 poin dari 90,00 menjadi 67,77; dan Kebebasan dari Diskriminasi turun 4,17 poin dari 74,32 menjadi 70,15. Dari data yang ditilik pada tahun 2013 banyak Parpol di DKI yang belum melakukan kegiatan kaderisasi atau melakukan kaderisasi tetapi tidak disampaikan saat dimintai data oleh petugas BPS selaku Pokja IDI, hingga akhirnya mendapatkan angka 0 . Oleh karenanya partisipasi Parpol dalam memberikan data yang dibutuhkan lengkap amat diperlukan agar IDI DKI Jakarta mencapai angka tertinggi atau tidak ke kategori buruk apalagi jatuh di angka 0 .

\section{Capaian IDI DKI Jakarta Tahun} 2014

Pada 2014, dimana pesta demokrasi Pemilu 2014 terjadi, DKI Jakarta mengalami kenaikan angka yang cukup besar. IDI DKI Jakarta 2014 sebesar 84,70, angka ini naik 13,52 poin dibandingkan dengan IDI DKI Jakarta 2013 sebesar 71,18, sehingga dengan nilai ini, IDI DKI Jakarta berubah dari kategori sedang pada tahun 2013 menjadi kategori baik pertamakalinya pada tahun 2014 .

Nilai IDI DKI Jakarta 2014 yang diukur dalam tiga aspek demokrasi seluruhnya mengalami peningkatan yang cukup signifikan dari tahun sebelumnya (2013). Indeks hak-hak politik mengalami peningkatan terbesar yaitu sebesar 18,86 poin, nilai indeks lembaga demokrasi meningkat sebesar 18,28 poin, dan nilai indeks kebebasan sipil meningkat 3,00 poin. Sehingga indeks Hak-Hak Politik (Political Rights) meningkat dari kategori buruk menjadi "sedang" dan indeks Lembaga-lembaga Demokrasi (Institution of Democracy) meningkat dari kategori sedang menjadi "baik", sedangkan indeks Kebebasan Sipil (Civil Liberty) masih sama berkategori "baik". Dari 11 variabel, yang naik hanya 8 variabel. Yang cukup fantastis, peningkatan terbesar pada variabel peran partai politik, yakni dari 10,00 (2013) menjadi 100,00 (2014). Lainnya peningkatan yang cukup berarti diantaranya hak memilih dan dipilih dari 52,64 menjadi 77, 18 dan partisipasi politik dalam pengambilan keputusan pengawasan dari 57,52 menjadi 70,71. Nampaknya dari perolehan nilai IDI 2014 ini, 
angka yang tersebar dalam bentuk skor pada masing-masing variabel cukup baik, tidak ada yang memperoleh skor di bawah 60, karena yang terendah hanya 66,26 yakni pada variabel Peran DPRD.

\section{Capaian IDI DKI Jakarta Tahun 2015}

Lonjakan perolehan nilai IDI DKI Jakarta tahun 2015 adalah yang tertinggi, yakni sebesar 85,32. Angka ini naik 0,62 poin dibandingkan dengan IDI DKI Jakarta 2014 sebesar 84,70, sehingga hasilnya IDI DKI Jakarta 2015 tetap berada pada kategori baik sama seperti tahun 2014. Kenaikan tersebut terjadi dari tahun 2014 ke 2015 dipengaruhi perubahan tiga aspek demokrasi yakni khusus Hak-Hak Politik (Political Rights) naik 9,25 poin (dari 73,94 menjadi 83,19) sehingga menjadikannya naik ke kategori "baik" dibanding tahun lalu (2014),. Sedangkan aspek Kebebasan Sipil (Civil Liberty) turun sedikitnya menjadi 2,08 poin (dari 91,72 menjadi 89,64), dan Lembagalembaga Demokrasi (Institution of Democracy) turun 9,71 poin (dari 92,97 poin menjadi 83,26 ), sehingga kedua aspek tersebut pada 2015 masih sama berkategori "baik" sepertihalnya tahun 2014.

Meskipun pada 2015 ini capaian IDI DKI Jakarta yang tertinggi, namun terdapat sejumlah penurunan.5 variabel yang mengalami penurunan skor dibanding tahun 2014, yaitu:

a. kebebasan berpendapat yang turun 6,94 poin dari 77,77 menjadi 70,83 ;

b. kebebasan berkeyakinan turun 2,58 poin dari 100 menjadi 97,42;

c. kebebasan dari diskriminasi turun 1,96 poin dari 77,10 menjadi 75,14

d. peran partai politik turun 1,99 poin dari 100 menjadi 98,01;

e. peran birokrasi pemerintah daerah turun 42,44 poin dari 100 menjadi 57,56 .

Sementara itu, empat variabel lainnya mengalami peningkatan skor, yaitu terdapat pada variabel: (a) kebebasan berkumpul dan berserikat meningkat 6,41 poin dari 91,25 menjadi 97,55; (b) hak memilih dan dipilih meningkat 0,08 point dari 77,18 menjadi 77,26; (c) partisipasi politik dalam pengambilan keputusan dan pengawasan meningkat 18,42 poin dari 70,71 menjadi 89,13; serta (d) peran DPRD meningkat 1,62 poin dari 66,26 menjadi 67,88 . 
Capaian IDI DKI Jakarta sebagaimana dijelaskan di atas, ada variabel aspek dan indikator yang perlu menjadi perhatian khusus agar nilainya dapat membaik, meskipun penurunan tersebut beberapa di antaranya masih terdapat kategori baik sekalipun (di atas 80). Misalnya pada variabel aspek peran partai politik turun 1,99 poin dari 100 pada 2014 menjadi 98,01 pada 2015. Meskipun mengalami sedikit penurunan, namun memerlukan perbaikan seperti semula.

Pada variabel aspek kebebasan berpendapat yang turun 6,94 poin dari 77,77 menjadi 70,83, diyakini di antaranya adalah terjadi pada kedua indikator berikut:

a. Ancaman /penggunaan kekerasan oleh aparat pemerintah yang menghambat kebebasan berpendapat dari 83,33 pada 2014 menjadi 75,00 pada 2015 .

b. Ancaman/penggunaan kekerasan oleh masyarakat yang menghambat kebebasan berpendapat 50,00 pada 2014 tetap tidak beranjak membaik yakni masih 50,00 pada 2015.

Ditengarai capaian pada indikator atas variabel kebebasan berpendapat di atas, dalam catatan penulis sepanjang 2015 di antaranya adalah:
1. Kontroversi dikeluarkannya Pergub 228/2015 (kemudian revisi no.232/2015) oleh Gubernur DKI Jakarta, Basuki Thahaja Purnama yang membatasi kebebasan berpendapat oleh publik ibukota. Meskpun kemudian Pergub sudah direvisi namun masih ada batasan yang bertentangan, di antaranya larangan menggunakan pengeras suara melebihi batas maksimal baku tingkat kebisingan hanya 60 desibel tidak sesuai dengan UU Nomor 9 Tahun 1998. Di UU Nomor 9 Tahun 1998 tidak diatur mengenai tingkat kebisingan, sehingga pergub ini harus ditolak. Selain itu juga dalam Pergub hasil revisi ini masih menyertakan TNI dalam kegiatan mediasi (Pasal 9 ayat 2), Koordinasi (Pasal 11 ayat 3) dan Pemantauan (Pasal 12 ayat 2), serta Evaluasi (Pasal 13 ayat 3,dan Pasal 14 ayat 3). Pergub telah menempatkan peran TNI bukan hanya di bidang pertahanan, tetapi juga memberikan ruang peran dan fungsinya di bidang keamanan dalam ranah pengendalian kebebasan berpendapat pada unjuk rasa warga sipil, dan ini mencederai demokrasi 
dan kepercayaan masyarakat dalam reformasi TNI.

2. Aksi Mogok kaum buruh yang dilakukan di berbagai tempat industri dan di jalanan ternyata dihadapi dengan kekerasan oleh hadangan warga sipil dan aparat keamanan. Aparat keamanan menggunakan dalih melarang aksi mogok nasional karena mogok nasional dianggap ilegal dan tidak dikenal dalam nomenklatur unjuk rasa. Mogok nasional menurut aparat dianggapnya hanya cukup dilakukan di dalam perusahaan karena itu hanya urusan mogok kerja. Bahkan tidak saja aparat, pihak sekelompok warga sipil pun sebagai pesanan pihak pengusaha yang berusaha ikut berlagak "preman" yang menebar ancaman dan tindak kekerasan untuk melarang aksi mogok nasional tersebut.

Sekedar catatan juga dari penulis, bahwa di luar kejadian yang tidak terinput atau tidak terkait dengan data informasi IDI pada 2015 terdapat berbagai peristiwa yang mewarnai situasi sosial politik di tengah masyarakat Ibukota Jakarta, adalah adanya animo politik yang tinggi sepanjang tahun 2015 sebagai puncak pertentangan politik antara Gubernur dan DPRD mengenai RAPBD 2015 yang berujung pada Hak Angket oleh DPRD, dan hal tersebut telah memancing massa tingkat bawah menggeruduk Balai Kota dan DPRD melakukan aksi unjuk rasa. Kegaduhan politik tersebut menciptakan ruang protes massa antara yang pro dan yang kontra menyikapi "Gubernur Bermulut Kotor" versus tudingan "Begal APBD di DPRD”. Aksi protes tersebut tidak saja ditumpahkan di depan halaman Balai Kota hingga jalan Kebon Sirih Jakarta Pusat, bahkan juga massa kerap memanfaatkan Car Free Day untuk aksi-aksi simpatik.

Termasuk sepanjang tahun 2015 juga ditandai banyaknya aksi pembangkangan warga terhadap kebijakan penggusuran (permukiman, lahan usaha, dan sarana sosial) yang menimbulkan gelombang protes demontrasi atau perlawanan massa sehingga timbul kekerasan yang mengancam kehidupan beberapa warga penghuni.

Sejak Januari hingga Desember 2015, berdasarkan Laporan Penggusuran Paksa di Wilayah DKI Jakarta yang dirilis oleh Lembaga Bantuan Hukum (LBH) Jakarta 
tercatat 113 kasus dengan jumlah 8.145 KK dan 6.283 unit usaha. Sebagian pelaku penggusuran paksa tersebut adalah Pemerintah Provinsi DKI Jakarta. Sebanyak 95 kasus (84\%) penggusuran paksa yang menimpa korban dilakukan secara sepihak oleh pelaku dan mayoritas warga sama sekali tidak diberikan solusi yang memadai. Ini artinya hampir seluruh kasus penggusuran paksa yang terjadi di wilayah DKI Jakarta tidak melalui prosedur musyawarah sebelum melaksanakan penggusuran. Sedikitnya hanya 18 kasus (16\%) yang diputuskan melalui musyawarah. Eksekusi penggusuran seringkali dilakukan dengan ancaman alat berat, juga tindakan penertiban oleh personil gabungan dari personil Satuan Polisi Pamong Praja (Satpol PP) yang ditopang personil TNI, dan personil POLRI.

\section{Capaian IDI DKI Jakarta Tahun 2016}

Tahun 2016 terjadi penurunan terhadap kualitas demokrasi di DKI Jakarta. Hal tersebut diperolehnya IDI Provinsi DKI Jakarta sebesar 70,85 yang mengalami penyusutan angka dibandingkan dengan IDI Provinsi DKI Jakarta 2015 yang capaiannya sebesar 85,32. Meskipun tingkat demokrasi Provinsi DKI Jakarta tersebut masih termasuk dalam kategori "sedang", nampaknya DKI Jakarta terpental diperingkat ke-14, jauh di bawah provinsi-provinsi lainnya di Indonesia, seperti DI Jogyakarta (85,58), Kep. Bangka Belitung (83,00), Nusa Tenggara Timur/NTT $(82,49)$, dan Sumatera selatan $(80,95)$.

Angka IDI Provinsi DKI Jakarta 2016 mengalami penurunan dari tiga aspek yakni:

a. aspek Kebebasan Sipil dengan angka 81,11 mengalami penurunan 8,53 poin dibandingkan tahun 2015;

b. aspek Hak-Hak Politik dengan angka 67,54 mengalami penurunan sebesar 15,65 poin; dan,

c. aspek Lembaga Demokrasi dengan angka 63,19 mengalami penurunan sebesar 20,07 poin, sehingga menjadi aspek yang mengalami penurunan nilai terbesar dan menempatkannya menjadi aspek dengan nilai terendah

Meskipun sama dengan tahun 2015, dimana tidak ada lagi indeks aspek yang berkategori "buruk" bagi 
IDI DKI Jakarta, namun pada 2016 dapat dibandingkan hasilnya, bahwa tahun 2015 semua indeks aspek berkategori "baik", sedangkan pada tahun 2016 Indeks aspek Hak-Hak Politik dan Lembaga Demokrasi turun menjadi kategori "sedang", hanya aspek Kebebasan Sipil yang tetat berada pada kategori "baik".

Penurunan pada aspek tersebut di atas, dapat diihat dari sejumlah variabel, dua di antaranya dari 9 variabel yang menurun cukup tajam. Pertama, Peran Birokrasi Pemerintah Daerah menurun paling tajam yaitu sebesar 53,04 poin, dari 57,56 pada 2015 menjadi 4,52 pada 2016. Kedua, terjadi pada variabel Kebebasan Berkumpul dan Berserikat yang turun 49,22 poin, dari 97,66 pada 2015 menjadi 48,44 pada 2016 .

Selain itu dapat juga dilihat dari hasil kinerja indikator demokrasi yang berkategori “buruk”(atau skor di bawah 60) di tahun 2016, yaitu:

a. Indikator 1, Ancaman kekerasan atau penggunaan kekerasan oleh aparat pemerintah yang menghambat kebebasan berkumpul dan berserikat.

b. Indikator 2, Ancaman kekerasan atau penggunaan kekerasan oleh masyarakat yang menghambat kebebasan berkumpul dan berserikat

c. Indikator 4, Ancaman/Penggunaan Kekerasan oleh Masyarakat yang Menghambat Kebebasan Berpendapat

d. Indikator 8, Aturan tertulis yang diskriminatif dalam hal gender, etnis atau terhadap kelompok rentan lainnya

e. Indikator 16, Demonstrasi/Mogok yang Bersifat Kekerasan

f. Indikator 21, Perda yang Merupakan Inisiatif DPRD

g. Indikator 22, Rekomendasi DPRD Kepada Eksekutif

h. Indikator 23, Kegiatan Kaderisasi yang Dilakukan Peserta Pemilu

i. Indikator 25, Jumlah kebijakan pejabat pemerintah daerah yang dinyatakan bersalah oleh keputusan PTUN, dan

j. Indikator 26,Upaya Penyediaan Informasi APBD oleh Pemerintah Daerah.

Dapat terekam dari berbagai media, bagaimana situasi politik demokrasi di DKI Jakarta tergambar di masa sepanjang tahun 2016, dan masuk dalam kenangan buruk masyarakat dan termasuk kinerja pemerintah daerah. Misalnya selain ancaman kekerasan terhadap 
kebebasan berpendapat yang dilakukan masyarakat, juga ancaman terjadi dilakukan oleh aparat pemerintah sendiri. Sebagai contoh kejadian penghadangan atau penolakan warga atas kedatangan Basuki Thahaja Purnama (Ahok) di sejumlah tempat oleh masyarakat yang kerap menimbulkan gejolak kekerasan, juga adanya pengusiran wartawan atau awak media yang hendak meliput berita oleh Gubernur DKI saat itu, Basuki Thahaja Purnama. Tindakan Gubernur DKI tersebut dikategorikan menghalangi kebebasan dalam berpendapat. Selama 2016, selain banyak kejadian-kejadian politik masa Pilkada yang menggangu demokrasi, seperti penghadangan, demontrasi dengan kekerasan, juga dipicu peran birokrasi pemerintah daerah (sebesar 4,52) yang terendah nilainya, serta kinerja legislatif (DPRD) yang minim hak inisiatif dalam menyusun Perda, sampai rendahnya rekomendasi pada eksekutif.

\section{Capaian IDI DKI Jakarta Tahun 2017}

Sebagaimana telah disebutkan di awal, bahwa capaian IDI secara nasional 2017, perolehan IDI Provinsi
DKI Jakarta adalah capaian angka yang tertinggi (sebesar 84,73) di Indonesia dan bersama tiga provinsi lainnya, yakni DI Jogyakarta(83,61), Kalimantan Utara $(81,06)$, dan Bangka Belitung (80,11). Bahwa 4 Provinsi tersebut berada pada kategori baik karena memiliki indeks di atas angka 80 .

Bagi DKI Jakarta, jelasnya capaian IDI 2017 merupakan prestasi yang luar biasa karena mampu membalikkan keadaan dari tahun sebelumnya yang terpuruk pada peringkat ke-14 pada IDI tingkat Provinsi di Indonesia.

IDI Provinsi DKI Jakarta 2017 mencapai angka 84,73 karena adanya kenaikan yang signifikan dibandingkan tahun 2016 yang angkanya 70,85, sehingga capaian kinerja demokrasi 2017 menempatkan DKI Jakarta pada kategori "baik". Kenaikan terjadi dari nilai indeks tiga aspek yakni:

a. indeks aspek Kebebasan Sipil bernilai 87,73 yang mengalami kenaikan 6,62 poin dibandingkan tahun 2016, ini menjadi aspek dengan capaian yang tertinggi;

b. indeks aspek Hak-Hak Politik yang bernilai 80,86 yang mengalami 
kenaikan sebesar 13,32 poin dibandingkan 2016; dan

c. indeks aspek Lembaga Demokrasi yang bernilai 87,06 yang mengalami kenaikan sebesar 23,93 poin.

Pada tahun 2017 tidak ada lagi indeks aspek yang berkategori "buruk" dan "sedang", mengingat ketiga indeks aspek di atas berkategori "baik". Pada tahun 2017 terdapat satu variabel yang mengalami penurunan indeks, tujuh variabel yang mengalami peningkatan dan tiga variabel yang tidak berubah (tetap). Variabel Kebebasan Berpendapat menurun cukup tajam yaitu sebesar 41,65 poin, dari 62,48 pada 2016 menjadi 20,83 pada 2017. Kenaikan terbesar terjadi pada variabel Peran Birokrasi Pemerintah Daerah yang naik 63,52 poin, dari 4,52 pada 2016 menjadi 68,04 pada 2017.

Namun demikian, dari capaian peringkat tertinggi tersebut, bukan berarti minim dari kekurangan, karena justru masih banyak pekerjaan rumah untuk memperbaiki kinerja demokrasi dari segi kinerja indikator demokrasi yang buruk selama 2017 (disebut berkategori "buruk" karena perolehan skor di bawah 60): a. Indikator 2, Ancaman kekerasan atau penggunaan kekerasan oleh masyarakat yang menghambat kebebasan berkumpul dan berserikat

b. Indikator 3, Ancaman kekerasan atau penggunaan kekerasan oleh aparat pemerintah yang menghambat kebebasan berpendapat

c. Indikator 4, Ancaman kekerasan atau penggunaan kekerasan oleh masyarakat yang menghambat kebebasan berpendapat

d. Indikator 21, Perda yang berasal dari hak inisiatif DPRD terhadap jumlah total perda yang dihasilkan

e. Indikator 22, Rekomendasi DPRD kepada eksekutif

f. Indikator 26, Upaya Penyediaan Informasi APBD oleh Pemerintah Daerah.

Perolehan skor yang buruk dari kinerja demokrasi berdasarkan indikator-indikator tersebut di atas, maka diperlukan perhatian khusus dari semua pihak, baik kalangan dari aparatur pemerintahan, lembaga perwakilan (DPRD), penegak hukum, penyelenggara Pemilu, dan dari kalangan masyarakat, baik Partai Politik, NGO, dan sebagainya memanfaatkan hasil IDI digunakan 
sebagai masukan bagi penyusunan program penguatan nilai-nilai, kultur dan struktur demokrasi agar kelak capaian kinerja demokrasi makin membaik. Di sinilah pentingnya memanfaatkan hasil pengukuran IDI terhadap kinerja demokrasi di DKI Jakarta, baik melalui stakeholder dalam hal ini pemerintah dan elemen masyarakat dalam bentuk Kelompok Kerja (Pokja) IDI Provinsi DKI Jakarta dan kalangan luas yang menjadi pelaku demokrasi di Ibukota Jakarta.

\section{Kekurangan dan Penguatan Pokja IDI di Tingkat Provinsi DKI Jakarta}

Meskipun menggunakan alat ukur yang obyektif dengan didukung oleh metodologis yang kuat, namun IDI tetap masih terdapat sejumlah kelemahan di dalam "meneropong" dinamika demokrasi yang terjadi secara keseuruhan. Hal tersebut dapat dilihat berikut ini:

1. Dari segi kepesertaan, tidak semua Partai Politik terlibat dalam FGD IDI. Dalam beberapa kesempatan melakukan FGD IDI untuk "membongkar" kasus yang terjadi selama setahun yang tengah dikaji hanya melibatkan 2 (dua) parpol (setidaknya sepanjang 2010 sampai 2015 dalam pengamatan penulis) yakni PKPI dan PBB DKI Jakarta dikarenakan keduanya tidak memperoleh kursi di DPRD dengan argumen untuk pemenuhan dokumen. Mengingat parpol yang memiliki suara di parlemen memiliki banyak peran atau terlibat dalam peristiwa politik dalam dinamika legislatif dan eksekutif sehingga dimungkinkan memiliki data atau dokumen mengenai kiprah partai politiknya dalam pelembagaan demokrasi di tingkat lokal. Meskipun pada 2016 dan 2017 terjadi penambahan keikutsertaan partai poltik secara bergantian, namun belum semuanya terlibat, sehingga pada akhirnya tidak banyak memberikan laporan mengenai kejadian politik.

2. Tingkat kesulitan dalam melacak atau merekam peristiwa yang sudah lewat selama 1 tahun kejadian, apalagi hanya mengandalkan berita hanya pada 1 (satu) koran harian sebagai sampel (salah satu dari Wartakota atau Poskota) sebagai dasar ada tidaknya mempertanyakan kasus yang terjadi dalam setahun pada 
indikator sesuai variabel yang dikaji dalam pengukuran IDI. Mengkaji IDI dilakukan beberapa bulan setelah melewati tahun tersebut sehingga banyak kasus kejadian luput dalam perekaman dan ingatan peserta FGD IDI sehingga tidak banyak melengkapi data dan informasi yang diperlukan. Apalagi keberadaan Pokja IDI belum jelas peran keanggotaannya untuk melakukan penyelidikan, termasuk antisipasi dan pengawalan IDI dalam memperbaiki kinerja demokrasi tahun berikutnya. Meskipun demikian, harus diakui penggalan isu muncul "sepotong-sepotong" dalam Kliping 1 Koran dan FGD harus didalami kembali melalui In-dept interview untuk mengurangi bias dalam data dan informasi yang diperoleh dengan para pakar/ahli/narasumber, tokoh, atau aktor organisasi yang menjadi saksi atau memiliki informasi atas kasus-kasus yang terkait dengan data sehingga didapat keabsahan data yang diperlukan sesuai rekomendasi FGD. Meskipun lagilagi, peritiswa yang dicatat hasil FGD dan interview akan dihitung jika dikategorikan sebagai peristiwa atau kejadian demokrasi tersebut dinyatakan "layak" sesuai kepentingan indikator menurut "Dewan Pakar".

3. Jumlah pengaduan masyarakat dalam layanan publik di sejumlah wilayah di Jakarta belum semuanya dapat terangkum (uncovered), khususnya pada layanan publik di berbagai institusi Pemprov atau SKPD. Banyak pengaduan publik dilakukan di berbagai lembaga yang sulit direkapitulasi sejak tingkat unit-unit teknis pelayanan publik, di instansi kelurahankelurahan, Puskesmas kecamatan, hingga instansi pemerintah Kab/Kota sampai SKPD Provinsi. Di institusi Pemprov DKI juga banyak tersebar pada lembaga yang menerima dan menganalisa pengaduan. Belum lagi pada instansi di luarnya seperti Komisi Ombdusman, hingga institusi kemasyarakatan lainnya yang sulit disinkronkan menjadi kesatuan pengaduan pelayanan publik secara utuh dalam waktu singkat di FGD.

4. Isu-isu politik nasional yang menjadi aktivitas politik keseharian di Ibukota yang cukup 
kompleks dan beragam kepentingan, sehingga wacana dan praktik politik negara banyak mewarnai puspa ragam demokrasi Jakarta. Inilah yang merumitkan analisa demokrasi di Ibukota. Banyaknya laporan aksi demontrasi di Jakarta berdasarkan laporan kepolisian tidak melulu tentang masalah Ibukota tapi juga masalah nasional dan bahkan isu lokal dari wilayah provinsi lain sehingga menjadikan Jakarta populer disebut "kota demo". Dapat dilihat misalnya aksi unjuk rasa yang bersifat nasional kerap tumpah di jalanan Ibukota, seperti hari buruh, hari sumpah pemuda, hari kebangkitan nasional (setiap 20 Mei) yang mendekati hari peristiwa reformasi (21 Mei) hingga adanya aksi penolakan UU atau Peratuan pusat lainnya. Termasuk juga isu lokal di luar daerah Jakarta yang menyemarakan unjuk rasa di kota Jakarta seperti aksi unjuk rasa tentang kasus agraria, hingga gerakan protes ke MK atau KPK mengenai kasus Pemilukada dan Korupsi di daerahnya. Isu lokal dari luar wilayah nampaknya dapat dikesampingkan dalam data
IDI di DKI, namun memilah isu nasional yang juga diramaikan oleh partisipasi warga lokal Ibukota harus mendapat perhatian. Seperti aksi buruh yang menolak PP 78/2015 sebagai isu nasional mengenai mekanisme upah yang menghilangkan peran Tripartit di daerah daerah menjadikan banyak wilayah aksi secara serentak di depan pemerintah daerah masingmasing, karena kejadian di Ibukota, di depan istana negara ricuh menjadi dicatat sebagai peristiwa lokal Jakarta.

5. Pemilukada sebagai wajah perpolitikan di tingkat lokal belum menjadi parameter untuk berkontribusi pada pengukuran IDI. Dalam suatu dialog di Asrama Sunan Giri (ASG) Rawamangun Jakarta Timur (dekat Kampus UNJ) pada 2016, Dewan Pakar IDI, Prof. Dr. Maswadi Rauf MA menyatakan bahwa Pemilukada sulit diukur karena penyelenggaraannya tidak merata. Sedangkan mengukur IDI setiap tahun dilakukan di daerah yang belum tentu setiap daerah tersebut telah menyelenggarakan Pemilukada. Meskipun demikian, segala kejadian politik selama di 
pilkada dicatat sebagai peristiwa demokrasi, meskipun tidka sepenuhnya terinput, seperti soal keikutsertaan masyarakat yang tercantum dalam data pemilih. Sehingga dari kesulitan inilah, maka menjadikan Pemilu 5 tahunan yang serentak seperti Pilleg dan Pilpres masih menjadi acuan mengukur data IDI. Ini terlewatkan begitu saja, mengingat sudah 3 kali Pemilukada di DKI Jakarta tahun 2007, 2012, dan 2017 selalu berjalan lebih terbuka, demokratis dan berjalan damai, tanpa adanya protes atau gugatan yang berujung sengketa di di MK. Kompetisi kalah-menang dalam Pilkada di DKI Jakarta selalu diterima sebagai bagian dari kedewasaan politik demokrasi masyarakat Ibukota tersebut selalu diapresiasi oleh pemerintah dan masyarakat luas, namun “disayangkan" kurang mendapat tempat dalam pengukuran demokrasi lokal pada indikator IDI DKI.

Dari sejumlah kekurangan tersebut di atas, setidaknya dapat dinyatakan bahwa tidak ada demokrasi yang mencapai predikat baik yang "sempurna" bagi suatu wilayah dalam negara untuk selesai menjadi yang paling demokratis. Meskipun Jakarta sebagai Ibukota Negara RI yang menjadi barometer politik demokrasi secara nasional dengan pengalamannya di peringkat tertinggi dalam capaian demokrasi di tingkat Provinsi sesuai capaian IDI 2017 dan bahkan melampaui angka IDI secara nasional. Namun demikian, berdasarkan pengalaman demokrasi lokal di Ibukota Jakarta yang mengalami pasang surut dalam dinamika politik lokal dan nasional yang mempengaruhinya, dan kemudian terekam dalam "potret" IDI. Maka dengan demikian IDI Provinsi DKI Jakarta menjadi wajah demokrasi Jakarta yang capaiannya harus diapresiasi dan dimanfaatkan untuk penyusunan program dan kebijakan yang mendorong pembangunan politik di Ibukota.

Sehingga, sebagaimana diungkap dalam kerangka konseptual tulisan ini, bahwa jika suatu negara gagal menterjemahkan substansi demokrasi dalam praktiknya, namun pada dasarnya negara tersebut dapat berusaha menyusun format demokrasi melalui sejumlah program dan kebijakan di dalam pemerintahan agar 
sejalan dengan kaidah atau kriteriakriteria (aspek-aspek yang menjadi variabel dan indikator) demokrasi dalam rangka memperbaiki atau menguatkan pembangunan politik dan kualitas demokrasi dalam pemerintahan.

Demikian pula, mengingat demokrasi sulit dibakukan dalam bentuk yang pasti secara definitif, maka sejumlah kriteria demokrasi yang ada dapat menjadi ukuran demokratisnya suatu negara atau wilayah, maka IDI sebagai bentuk pengukuran yang khas Indonesia dari sejumlah prinsip dan kaidah demokrasi yang universal. Sebagaimana dijelaskan dilatar belakang dan kerangka konseptual bahwa capaian IDI amat penting untuk dijadikan parameter bagi capaian pengembangan demokrasi sekaligus pembangunan politik di daerah. Dari hasil pengukuran IDI dapat dilihat kualitas demokrasi suatu provinsi (kondisi dan dinamika demokrasi suatu daerah) yang melibatkan peran pemerintah, instansi publik dan partai politik maupun masyarakat luas.

Pemerintah mendorong daerah untuk meningkatkan capaian dari parameter demokrasi tersebut melalui Surat Edaran Menteri Dalam Negeri
Nomor 200/526/SJ tanggal 21

Februari 2012 tentang Pembentukan Kelompok Kerja (Pokja) Pengembangan Demokrasi Provinsi guna memantapkan capaian dan pengembangan IDI di Provinsi, sebagai berikut melalui Keputusan Gubernur yang mengacu pada format struktur organisasi, dimana Sekretaris Daerah sebagai Ketua Pokja, Ketua Komisi A (Bidang Pemerintahan) DPRD sebagai Wakil Ketua Pokja dan Kepala Badan Kesatuan Bangsa dan Politik sebagai Sekretaris Pokja, dengan menambah keanggotaan unsur Komando Daerah Militer/Komando Resort Militer, Kepolisian Daerah (Polda), dan kanwil Kementerian Hukum dan HAM; selain melibatkan unsur masyarakat sipil. Adapun tugas utama Pokja IDI, yaitu: (1) Memberi masukan strategi pemanfaatan IDI; (2) Melakukan quality assurance dalam pengumpulan data; (3) Terlibat aktif di dalam pelaksanaan pemanfaatan IDI, termasuk membantu proses pendampingan; (4) Terlibat aktif dalam upaya diseminasi IDI Tingkat Provinsi; (5) Memberi masukan penyempurnaan indikator dan metodologi IDI. Surat edaran juga mendorong kepada daerah untuk mengalokasikan anggaran dalam 
APBD untuk pelaksanaan kegiatan Pokja

Keseriusan

pemerintah mendorong peningkatan IDI tersebut juga dikeluarkannya Surat Menteri Dalam Negeri Nomor 200/618/SJ tanggal 4 Februari 2015 perihal Pelaksanaan Demokrasi di Daerah dan Surat Menteri Koordinator Politik Hukum dan Keamanan (Menkopolhukam) Nomor: B33/Menko/Polhukam/DN.02.02.4/3/20 16 tertanggal 17 Maret 2016 perihal Optimalisasi Peran dan Fungsi Pokja Pengembangan Demokrasi Provinsi.

Selain itu juga sesuai Peraturan Presiden Nomor 2 Tahun 2015 tentang Rencana Pembangunan Jangka Menengah Nasional Tahun 20152019, Pemerintah bertekad mewujudkan konsolidasi demokrasi yang salah satunya diukur melalui capaian Indeks Demokrasi Indonesia (IDI), dan target pembangunan politik sebagaimana dalam UU No. 17 Tahun 2007 tentang RPJPN 2005-2025.

Berdasarkan Surat Edaran Menteri Dalam Negeri RI Nomor 200/1147/ SJ tertanggal 6 April 2016 tentang Pelaksanaan Kelompok Kerja (Pokja) Demokrasi di Daerah mempertegas kepada Gubernur setiap provinsi di daerah menyusun Rencana
Aksi Pengembangan Demokrasi di Daerah dan melaporkan hasil perencanaan dan pelaksanaannya kepada Menteri Dalam Negeri Cq. Direktur Jenderal Politik dan Pemerintahan Umum. Selain itu juga peran Sekretaris Daerah Provinsi selaku Ketua Pokja Pengembangan Demokrasi Daerah untuk lebih optimal dan serius dalam meningkatkan komunikasi, koordinasi dan pemberdayaan peran kepengurusan Pokja. Pemberdayaan dimaksud dapat melalui memasukkan program IDI ke dalam Rencana Pembangunan Daerah (RPJMD) Provinsi, Kabupaten, dan Kota dan/atau melalui Rencana Kerja Pemerintah Daerah (RKPD) sebagai bagian dari pembangunan bidang ideologi Pancasila, wawasan kebangsaan, dan politik di daerah.

Termutakhir, melalui Permendagri Nomor 134 Tahun 2017 tentang Perubahan atas Peraturan Menteri Dalam negeri Nomor 33 Tahun 2017 tentang Pedoman Penyusunan Anggaran Pendapatan dan Belanja Daerah Tahun Anggaran 2018, dan berikutnya Peraturan Menteri Dalam Negeri Republik Indonesia Nomor 38 Tahun 2018 tentang Pedoman Penyusunan 
Anggaran dan Belanja Daerah Tahun Anggaran 2019 ddisertai Surat Edaran Menteri Dalam Negeri Nomor 200/7570/SJ tanggal 26 September 2018 terkait Penguatan Kelompok Kerja (Pokja) Demokrasi di Daerah, yakni agar setiap daerah menyusun Rencana Aksi Penguatan Pokja IDI di tiap-tiap Provinsi. Sebagaimana dalam Arah dan Kebijakan Pemerintah Dalam Pembangunan Demokrasi Sesuai Amanat RPJMN oleh Kasubdit Fasilitasi Lembaga Pemerintahan dan Perwakilan (2019), dan mengintegrasikan IDI terhadap misi Pemda dalam bidang pembangunan politik, mensinergikan aspek dan variabel IDI dengan Rencana Kerja Pemerintah Daerah (RKPD), dan mengoperasionalkannya dalam bentuk program jangka pendek dan jangka menengah daerah, dan sekaligus Data IDI dapat dijadikan sebagai salah satu sumber informasi dalam penyusunan RPJMD. Dengan demikian, capaian IDI dapat menjadi bahan diseminasi dan pemanfaatan hasil bagi stakesholder, khususnya bagi pemerintah untuk membantu perencanaan pembangunan yang lebih baik, mendorong kebijakan publik yang berbasis data empirik (evidence based policy).
Keberadaan Pokja IDI di DKI Jakarta belum difungsikan secara maksimal, kecuali sekedar pertemuan yang diselenggarakan secara formal oleh Badan Kesatuan Bangsa dan Politik (Bakesbangpol) Pemprov DKI Jakarta guna mendiskusikan hasil IDI untuk kepentingan penguatan capaian IDI yang akan datang khususnya. Sudah semestinya Pokja IDI DKI Jakarta diberdayakan melalui kegiatan perencanaan hingga pengawasan, maupun kegiatan sosialisasi pada kalangan yang lebih luas, khususnya pengurus partai politik, dan ormas/LSM/perkumpulan masyarakat, dan kalangan organisasi kepemudaan/kemahasiswaan. Di kalangan pemerintah daerah, mulai dari yang terbawah, kelurahan dan kecamatan juga mestinya menjadi sasaran sosialisasi dan termasuk melakukan dialog bersama kalangan DPRD berikut jajaran sekretariat DPRD dalam rangka meningkatkan kualitas demokrasi.

\section{PENUTUP}

\section{Kesimpulan}

Dari pembahasan di atas dapat disimpulkan bahwa demokrasi sebagai sistem politik di suatu daerah atau negara memerlukan dukungan struktur demokrasi 
yang baik, yakni berupa pemerintahan yang mempraktikan demokrasi sesuai konstitusi dan perundang-undangan yang berlaku, serta meminimalir tindakan aparat yang menimbulkan anti demokrasi maupun kebijakan pemerintah yang merugikan kepentingan publik lainnya. Selain itu juga demokrasi memerlukan perilaku yang mencerminkan nilai-nilai demokrasi demi terbangunnya kultur demokratis dari kalangan masyarakat pendukungnya. Semuanya tersebut tercermin dalam berbagai kriteria demokrasi yang menjadi aspek-aspek pengukuran indeks demokrasi suatu daerah atau negara.

Pada 5 tahun terakhir, tingkat demokratisnya Jakarta sebagai Ibukota Negara RI mengalami pasang surut sesuai dinamika politik lokal dan nasional yang mempengaruhinya . Hal tersebut dapat terekam dalam capaian hasil IDI DKI Jakarta setiap tahunnya yang menunjukkan pemeringkatan kualitas demokrasi antar Provinsi secara nasional sesuai pengukuran dari berbagai aspek, variabel dan indikator yang digunakan dalam Indeks Demokrasi Indonesia. Meskipun Jakarta sebagai wilayah yang kecil dibanding provinsi-provinsi lainnya di Indonesia, khususnya bagian Jawa yang padat penduduk dan banyaknya jumlah pemerintahan Kabupaten dan kotanya, namun Jakarta sebagai Ibukota Negara kerap diramaikan oleh sejumlah perpolitikan nasional dan lokal yang saling mempengaruhi kinerja dari aspek-aspek demokrasi.

Dari keseluruhan hasil capaian IDI Provinsi DKI Jakarta terakhir (2017) berada pada kategori baik dan tertinggi dibanding capaian IDI provinsi lainnya dan bahkan melampaui capaian IDI Nasional. Sehingga dari kategori inilah yang menjadikan Jakarta merupakan sebuah "barometer" nasional bagi capaian demokrasi.

Namun, dari capaian tersebut, juga terdapat catatan untuk terus diperbaiki karena masih dijumpai penurunan angka sehingga terjadi kelemahan dari aspek dan indikator tertentu yang tertinggal dari angka atau indeks aspek dan indikator dari provinsi lain yang menggambarkan wajah demokrasi Jakarta sepanjang tahun, seperti masih adanya ancaman atau penggunaan kekerasan baik yang dilakukan oleh pemerintah dan masyarakat yang menghambat kebebasan dalam berpendapat, berkumpul/ berserikat sebagaimana yang terjadi pada 2017.

Selain isu-isu nasional di DKI yang mempengaruhinya, juga dapat dilihat dari sejumlah variabel aspek dan indikator dalam mengukur peristiwa di Jakarta yang kerap terjadi penurunan kualitas 
demokrasi, setidaknya terdapat beberapa kebijakan yang dikeluarkan pemerintah daerah perlu mendapat perubahan atau revisi seperti Perda Ketenagakerjaan yang masih menunjukkan adanya diskriminasi pada kaum perempuan, dan Pergub yang membatasi kebebasan menyatakan pendapat di muka umum. Termasuk variabel lainnya meliputi kinerja DPRD dalam membuat Perda Inisiatif dan jumlah Rekomendasi kepada eksekutif perlu menjadi perhatian khusus agar nilainya dapat membaik.

Demikian juga pentingnya partaipartai politik melakukan pendidikan politik secara kontinyu serta memaksimalkan pelibatan kaum perempuan. Juga perilaku masyarakat dalam menyampaikan kebebasan berpendapat perlu mendapat jaminan perlindungan dan menyampaikannya secara damai, sehingga dengan demikian, perlunya Pemerintah Daerah Provinsi DKI bersama elemen masyarakat luas lainnya ikut mendorong dan memfasilitasi Pokja IDI yang berguna bagi pengembangan demokrasi di daerah dan Pokja IDI yang terbentuk bergerak lebih optimal sesuai peran dan fungsinya, baik sejak dalam input dokumen, hingga pembahasannya baik oleh FGD sampai konsultasi ke Dewan Ahli/Pakar, serta hasilnya dapat diberdayakan dengan memasukkan program IDI ke dalam Rencana Pembangunan Daerah (RPJMD) Provinsi, Kabupaten, dan Kota dan/atau melalui Rencana Kerja Pemerintah Daerah (RKPD). Pemerintah dan pemerintah daerah perlu melibatkan masyarakat sipil dalam penyusunan program dan kebijakan serta sosialisasi IDI. Dengan demikian capaian IDI benar-benar dapat menjadi bahan diseminasi dan pemanfaatan hasil bagi stakesholder demokrasi di Ibukota.

\section{DAFTAR PUSTAKA}

Amien Rais. 1986. Demokrasi dan Proses Politik. Jakarta: LP3ES.

Budiarto Danujaya. 2012. Demokrasi Disensus, Politik Dalam Paradoks. Jakarta: PT Gramedia Pustaka Utama.

Maswadi Rauf, dkk. 2012. Indeks Demokrasi Indoensia 2010, Kebebasan Yang Bertanggungjawab dan Substansial, Sebuah Tantangan. Jakarta: Badan Pusat Statistika.

Mirriam Budiardjo. 1990. DasarDasar Ilmu Politik. Jakarta: PT. Gramedia.

Mirriam Budiardjo. 1990. Demokrasi di Indonesia. Jakarta: PT. Gramedia.

Pangi Syarwi Chaniago. 2017. Demokrasi Konsensus,

Kontestasi Antara Suara Voting VS Suara Permusyawaratan. Jakarta: Voxpol Center Research\& Consulting.

Sarah Maxim (Peny.). 2002. Demokrasi di Tingkat Lokal, Buku Panduan International IDEA Mengenai Keterlibatan, 
Keterwakilan, Pengelolaan Konflik dan Kepemerintahan. Seri Buku Panduan. Jakarta: AMEEPRO.

Undang-Undang RI Nomor 9 Tahun 1998 tentang Kemerdekaan Menyampaikan Pendapat di Muka Umum.

Undang-Undang RI Nomor 39 Tahun 1999 tentang Hak Asasi Manusia.

Undang-Undang RI Nomor 23 Tahun 2014 tentang Pemerintah Daerah.

Undang-Undang RI Nomor 2 Tahun 2015 tentang Penetapan Peraturan Pemerintah Pengganti Undang Undang (Perppu) Nomor 2 Tahun 2014 tentang Perubahan Atas UU Nomor 23/2014 Menjadi UndangUndang.

Undang-Undang RI Nomor 9 Tahun 2015 tentang Perubahan Kedua Atas UU Nomor 23 Tahun 2014 tentang Pemerintah Daerah (disahkan dan diundangkan pada 18 Maret 2015 dalam Lembaran Negara Republik Indonesia tahun 2015 Nomor 58).

Undang-Undang RI Nomor 29 tahun 2007 tentang Pemerintahan Provinsi Daerah Khusus Ibukota Jakarta Sebagai Ibukota Negara Kesatuan Republik Indonesia.

Peraturan Gubernur Daerah Khusus Ibukota Jakarta Nomor 228 Tahun 2015 tentang PengendalianPelaksanaan Penyampaian Pendapat di Muka Umum Pada Ruang Terbuka.

Peraturan Gubernur Daerah Khusus Ibukota Jakarta Nomor 232 Tahun 2015 tentang PengendalianPelaksanaan

Penyampaian Pendapat di Muka Umum Pada Ruang Terbuka.

Peraturan Kepala Kepolisian Negara RI Nomor 7 tahun 2012 tentang
Tata Cara Penyelenggaraan Pelayanan, Pengamanan, dan Penanganan Perkara Penyampaian Pendapat di Muka Umum.

Surat Edaran Menteri Dalam Negeri RI Nomor 200/1147/ SJ tertanggal 6 April 2016 tentang Pelaksanaan Kelompok Kerja (Pokja) Demokrasi di Daerah.

Surat Menteri Dalam Negeri Nomor 200/618/SJ tanggal 4 Februari 2015 perihal Pelaksanaan Demokrasi di Daerah.

Surat Menteri Koordinator Politik Hukum dan Keamanan Nomor B-

33/Menko/Polhukam/DN.02.02. 4/3/2016 tanggal 17 Maret 2016 perihal Optimalisasi Peran dan Fungsi Pokja Pengembangan Demokrasi Provinsi.

Surat Edaran Menteri Dalam Negeri Nomor 200/526/SJ tanggal 21 Februari 2012 tantang Pembentukan Kelompok Kerja (Pokja) Pengembangan Demokrasi Provinsi.

Dokumen FGD IDI DKI Jakarta Tahun 2015 pada FGD IDI di Hotel Golden Jakarta, 25-26 Mei 2016.

Dokumen Presentasi Arah dan Kebijakan Pemerintah Dalam Pembangunan Demokrasi Sesuai Amanat RPJMN oleh Kasubdit Fasilitasi Lembaga Pemerintahan dan Perwakilan (2019).

Berita Resmi Statistik BPS DKI Jakarta No. 35/07/31/XVI, 7 Juli 2014 tentang IDI Provinsi DKI Jakarta Tahun 2013.

Berita Resmi Statistik BPS DKI Jakarta No. 40/08/31/th.XVII, 13 Agustus 2015 tentang IDI Provinsi DKI Jakarta Tahun 2014.

Berita Resmi Statistik BPS DKI Jakarta No. 35/08/31/th.XVIII, 3 
Agustus 2016 tentang IDI

Provinsi DKI Jakarta Tahun 2015.

Berita Resmi Statistik BPS DKI Jakarta No. 45/09/31/Th. XIX, 14 September 2017 tentang IDI Provinsi DKI Jakarta Tahun 2016.

Berita Resmi Statistik BPS DKI Jakarta No. 42/09/31/Th. XX, 3 September 2018 tentang IDI Provinsi DKI Jakarta Tahun 2017.

Berita Resmi Statistik BPS DKI Jakarta No. 69/08/th.XXI, 15 Agustus 2018 tentang IDI 2017. 